\title{
Pus. 1993
}

Draft of a published report: Shelly, J. S., P. Lesica, P.G. Wolf, P.S. Soltis, and D.E. Soltis 1998. Systematic Studies and Conservation Status of Claytonia Lanceolata Var Flava (Portalucaceae). Madrono 45(1): 64-74.

Systematics and Conservation status of Claytonia lanceolata var. flava (Portulacaceae)

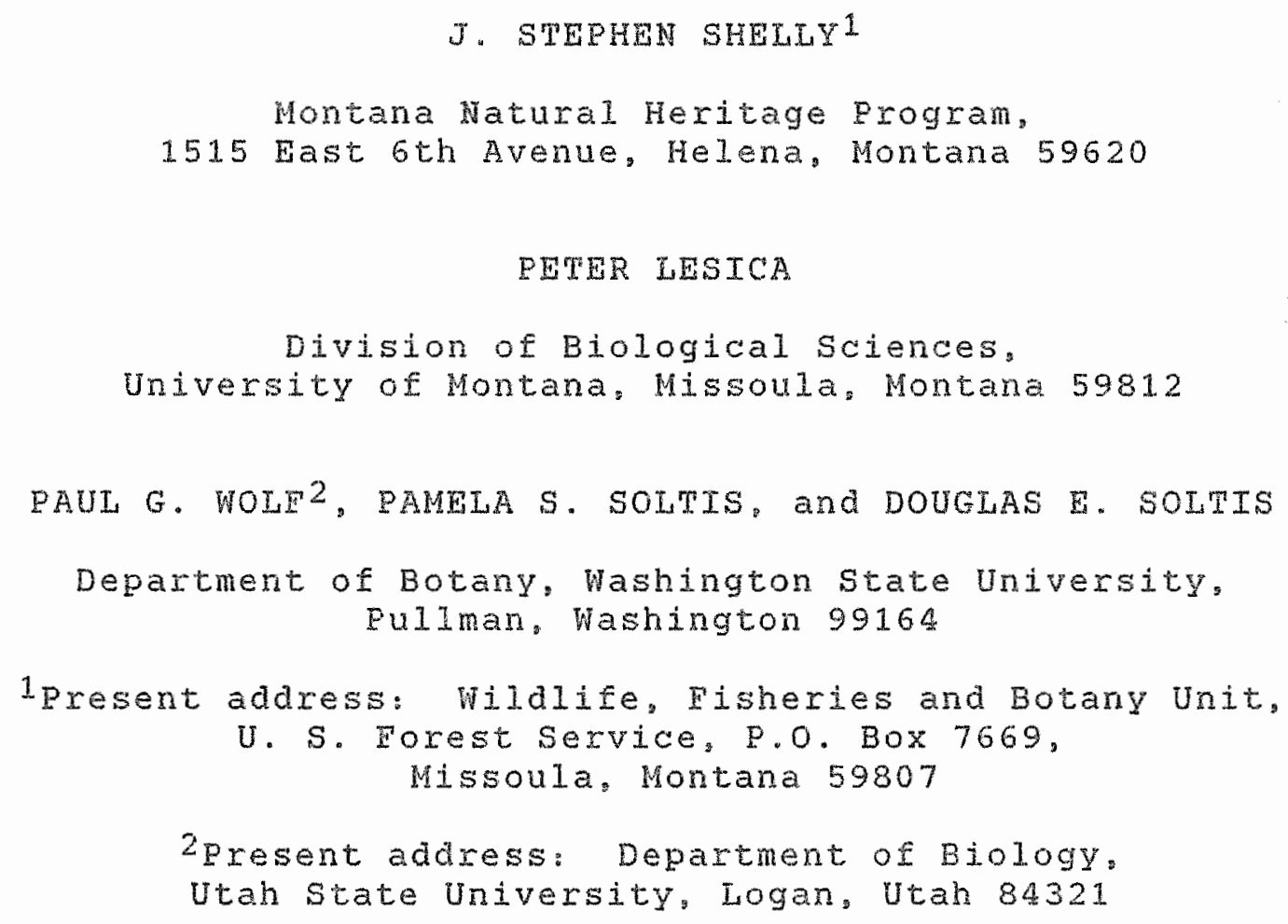


Systematics and conservation status of Claytonia lanceolaca var. Ilava (Portulacaceae)

\section{ABSTRACT}

A systematic study of Claytonia lanceolata and related taxa in the Rocky Mountains was conducted. The study was specifically undertaken to evaluate the taxonomic status of C. Ianceolata var. flava, as part of an assessment to determine the need for protection of the latter taxon under the federal Endangered Species Act. Dlectrophoretic and morphological studies revealed that populations of $\underline{c}$. lanceolata var. Elava in southwestern Montana and northwestern Wyoming represent a diploid $(n=8)$ species whose populations consist of yellow- and/or white-flowered plants. This taxon does not belong in the $\underline{C}$. lanceolata complex, but is best placed in the group of narrow-leaved species that includes $\underline{C}$. rosea, $\underline{C}$. tuberosa and $\underline{C}$. virginica. Numerous populations, most often consisting of the white-flowered phenotype, were found in Montana and Wyoming, and legal protection is not warranted at this time. In some cases. actions to conserve endangered plant taxa must be preceded by an evaluation of their taxonomic status: this study illustrates the utility of modern systematic techniques in conducting such evaluations.

\section{INTRODUCTION}

Claytonia lanceolata Pursh (Portulacaceae) is a common, wide-ranging species of western North America (Hitchcock et 
al. 1964). Claytonia lanceolata var. flava (A. NeIs.) C. L. Hitchc. has been applied to yellow-flowered populations in the northern Rocky Mountains (Davis 1966: Hitchcock et al. 1964). This unique variant was first collected in 1899 in Fremont County. Idaho (NeIson 1900). From 1911 to 1988, it was additionally collected at five stations in southwestern Montana (Shelly 1989) and one station in northwestern Wyoming (Marriott 1986). It was rediscovered at the type locality in 1986 (D. Atwood, pers. comm.). The infrequency of collection and the relatively restricted geographic range of these yellow-flowered populations led to the designation of C. Ianceolata var. Elava as a candidate for possible listing under the federal Endangered species Act of 1973 (U.S. Fish and Wildife service 1985).

As part of an evaluation to determine the need for such protective listing, we undertook a study to assess the placement of $c$. lanceolata var. Elava in that species, using isozyme electrophoresis and morphological comparisons with the common, wite-to pink-flowered $\underline{C}$. lanceolata var. lanceolata. Initial field surveys of known populations of C. Ianceolata var. Llava revealed the presence of narrowleaved, white-flowered plants that were morphologically very similar to the yellow-Elowered individuals, and which did not fit the descriptions of typically broader-leaved $\underline{C}$. lanceolata var. lanceolata. Thus, we also examined the degree of isozyme differentiation between white- and yellow- 
flowered individuals of these narrow-leaved plants, and whether any other morpological differences aside from petal color exist between them. Yellow- and white-flowered individuals of the narrow-leaved plants are biotically sympatric in four of the study locations, and $\underline{c}$. lanceolata var. lanceolata is biotically or neighboringly sympatric with the narrow-leaved plants in five of the study locations. Other closely related taxa included in this study were $c$. Ianceolata var. chrysantha (Greene) C. I. Hitchc., C. lanceolata var. multiscapa (Rydb.) C. L. Hitchc. and $\underline{C}$. rosea Rydb.

\section{TAXONOMIC HISTORY}

The first collection of a yellow-flowered claytonia in the northern Rocky Mountains was made in 1899 by Aven and Elias Nelson (5488, $R M$ ), near the northwest corner of Henry's Lake in Fremont County. Idaho. It was subsequently described as C. aurea (NeIson 1900). InterestingIy, Rydberg (1922) reduced this name to a synonym of $\underline{C}$. chrysantha Greene $1=\underline{C}$. Ianceolata var. chrysantha (Greene) C. L. Hitchc.. a yellowflowered form of the latter species occurring in western Washington (Douglas and Taylor 1972)), undoubtedly based on the shared flower color. Claytonia aurea was later renamed C. Elava, the former name having already been used by Kuntze in 1891 (NeIson 1926). Since that time, Claytonia flava has been reduced to a variety of $\underline{c}$. Ianceolata on two separate occasions, first by Hitchcock et al. (1964), and then by Davis (1966). The latter revision was perhaps in ignorance 
of the Hitchcock treatment, and Davis is occasionally cited as the author of this change. More recently, the taxon has again been treated as a full species (Dorn 1984).

The taxonomy of claytonia is currently being revised for the Flora of North America project (Miller 1992). Pending publication of this treatment, throughout this paper the name C. Ianceolata var. Elava will be used to discuss populations of both the white and yellow flower color phenotypes of the taxon, except when citing previous alternate treatments.

\section{MATERIALS AND METHODS}

Five populations of $\underline{C}$. lanceolata var. lanceolata and seven populations of $\mathrm{C}$. Lanceolata var. flava (including five of the yellow-flowered phenotype and seven of the whiteflowered phenotype) were sampled for field morphological studies and isozyme electrophoretic studies. In most cases. the same populations of each taxon or color phenotype were sampled for both studies. The study populations are located in southwestern Montana and northwestern Wyoming (Eig. 1, Table 1).

\section{Morphological studies}

Field and herbarium morphological studies were conducted. We emphasized characters that are easily examined on living plants and pressed specimens, and that have been used in past keys treating some or all of the taxa of interest. 
In the field, morphological data vere collected from 720 living plants, representing five populations of $\underline{C}$. lanceolata var. Ianceolata and eleven populations of $c$. lanceolata var. Elava (five yellow-flowered and six whiteflowered populations). In each population, 45 randomly chosen plants were examined for the following characters: stem height, leaf length and width, petal length and width, and sepal length. Stem height was measured in centimeters, from ground level to the point of attachment of the uppermost pedicel: all other lengths were measured in milimeters. For the computer analyses, the length/width ratios of the leaves and petals were also calculated.

In addition to the field studies, 184 herbarium collections, representing $\subseteq$. lanceolata vars. lanceolata, Elava. multiscapa, and chrysantha, as well as $\underline{C}$. rosea, were examined from the following herbaria: MOMTU, OSC, RM, UA, UAL, WSU, WTU (CHECK). In addition to the characters Iisted above, petal apex outline and cauline leaf venation were scored for the herbarium specimens (see Table 6 for scoring criteria).

\section{Isozyme glectrophoresis}

A total of 679 individuals, representing 15 populations (five of $C$. lanceolata var. lanceolata and five for each flower color phenotype of $\underline{c}$. Lanceolata var. flava): were sampled. Whole flowering stems, including the cauline leaves, were collected by clipping the plants at ground 
level. These were kept chilled in the field for one to several days until placement in ultracold storage $\left(-80^{\circ} \mathrm{C}\right)$.

Leaves were ground immediately upon removal from the ultracold freezer, in the Tris HCl-PVP crushing buffer of Soltis et al. (1983). Sixteen loci, representing ten enzymes, were resolved using three electrophoretic buffers. A morpholine buffer (pH 6.4; Ordzykoski and Gottlieb 1984) was used to resolve glyceraldehyde-3-phosphate dehydrogenase (G3PDH), malate dehydrogenase (MDH), and phosphoglucomutase (PGM). Buffer 8 of Soltis et al. (1983) was used to resolve alcohol dehydrogenase (ADH), aspartate aminotransferase (AAT), leucine aminopeptidase (LAP), phosphoglucoisomerase (PGI), and triosephosphate isomerase (TPI). Buffer 11 of Soltis et al. (1983) was used to resolve isocitrate dehydrogenase (IDH) and 6-phosphogluconate dehydrogenase (6PGD). The stain recipe for $A D H$ was that described by Wendel and weeden (1989). All other staining protocols were those described by soltis et al. (1983).

\section{Data Analysis}

We assessed the morphological distinctiveness of the various taxa using principal components analysis (PCA) and discriminant analysis. These analyses were performed using SYSTAT (Wilkinson 1986), and were based on the characters listed above. 
Electrophoretic data were analyzed using the computer program BIOSYS-1 (Swofford and selander 1981). Three separate analyses were performed: 1.) allele frequencies at 16 loci were entered for al1 15 populations and analyzed for genetic variability statistics and Nei's genetic identity among populations: 2.) allele frequencies at 16 loci were entered for the ten $\underline{C}$. Ianceolata var. Elava populations (including yeliow- and white-flowered phenotypes) and analyzed for Nei's genetic identity among populations: and 3.) eight C. Ianceolata var. Ilava populations from all localities except Hebgen Lake (all yellow-slowered) and Boulder (all white-flowered), were entered as genotype numbers and analyzed for population substructuring, to examine differences between color phenotypes within localities. An unweighted pair group method (UPGMA) was used for cluster analysis of Nei's genetic identity relationships.

\section{RESULTS}

\section{Morphological studies}

1. Field studies. Taron means, ranges, and standard deviations for the eight quantitative characters measured on living plants are given in Table 2 .

According to the loadings given in Table 3 , petal width. leaf length, stem height, leaf length/width ratio, sepal length, and petal length/width ratio made significant contributions to the first principal component. Characters 
contributing most to the second principal component included leaf width and petal length. The PCA of the field morphology data revealed that allopatric populations containing either narrow-leaved (‥ lanceolata var. flava) or broad-leaved (ć. lanceolata var. Ianceolata) plants are more similar to each other than are neighboringly sympatric populations of differing leaf morphology (Eig. 2). Aside from flower color, the yellow- and white-flowered individuals of $\underline{c}$. lanceolata var. Elava are highly similar morphologically, and are well-distinguished from $\underline{C}$. lanceolata var. lanceolata by the differences in leaf and petal shape (Fig. 2, Table 2).

In a discriminant analysis comparing the white- and yellowflowered individuals of $c$. Ianceolata var. flava, the crossvalidation error rate for the discriminant function was 0.42 : there is only a $58 \%$ chance of correctly identifying the two flower color phenotypes of $\underline{C}$. Ianceolata var. Ilava based on the morphological characters used in the analysis. Thus, the two phenotypes cannot be reliably discriminated on characters other than flower color.

\section{Herbarium Studies. Taxon means, ranges, and standard} deviations for the eight quantitative and two qualitative characters examined on the herbarium collections are given in Table 4. 
Leaf venation, petal apex outline, leaf length/width ratio, leaf width, petal/sepal length ratio, and sepal length were the characters contributing most to the first principal component (Table 5). Petal width and length contributed significantly to the second principal component. The PCA of the herbarium morphological data indicated that claytonia rosea and $C$. lanceolata vars. flava and multiscapa are all morphologically distinct from C. lanceolata var. lanceolata, and are very similar to one another (Fig. 3 ).

\section{Isozyme Electrophoresis}

Each isozyme was treated as a genetic locus and each allozyme as an allele. Coding of populations of $\underline{c}$. lanceolata var. Elava was straightforward, as simple diploid expression was observed in all of them. However, $\underline{C}$. lanceolata var. lanceolata expressed more complex tetraploid banding patterns. In order to make comparisons among varieties and flower color phenotypes at each locality. it was necessary to code allele frequencies for $\underline{\mathrm{C}}$. lanceolata vax. Ianceolata. This was done by assuming that each individual was tetraploid and possessed four doses of allozymes (alleles). Some individuals, therefore, expressed more than two alleles at a locus. Relative staining intensities were used to decernine dosage effects (Wolf 1988). Allele frequencies are given in Table 6.

\section{Differences between varieties. A UPGMA cluster} analysis of Nei's genetic identity values is shown in Fig. 
4. Owing to allelic differences between them, all 5 populations of $C$. Ianceolata var. lanceolata were completely separated from the ten populations of $\mathrm{C}$. lanceolata var. flava (represented by samples of both white- and yellowflowered plants). The mean genetic identity between populations of these two taxa was 0.69 (WILI NEED TO REVISE THIS).

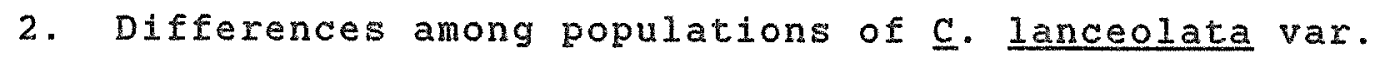
Elava. The UPGMA cluster analysis also indicates the level of differentiation among populations, either yellow- or white-flowered, of C. Ianceolata var. Elava (Fig. 4). Genetic identity values among the six localities ranged from 0.870 (Boulder [all white-flowered plants] compared to Hebgen [yellow-flowered]) to 0.989 (Anaconda [whiteflowered] compared to Champion [both yellow and white phenotypes]). The genetic identities correspond to geographic proximity; the Hebgen uake and Wyoming populations clustered together, as did the Anaconda, Champion, and vipond populations farther to the northwest in Montana. The Boulder population is the most genetically

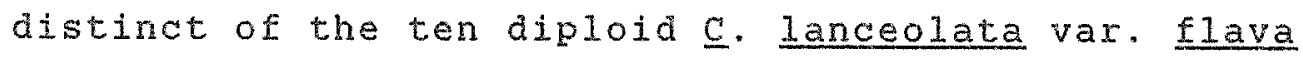
populations sampled: the mean genetic identity of this population to the other nine is 0.895 .

3. Differences between color phenotypes within populations of C. Ianceolata var. Elava. In the four cases where they 
are biotically sympatric, yellow- and white-flowered

"populations" of $\underline{C}$. lanceolata var. flava were more similar to each other than to allopatric populations of the same flower color (Fig. 4). The Nei's genetic identity values between color phenotypes within localities were high, ranging from 0.995 (Vipond Park) to 1.00 (Anaconda) (Table 7).

\section{DISCUSSION}

Morphological studies and isozyme electrophoresis first revealed that $\underline{C}$. lanceolata var. Elava represents a distinct diploid species $(2 \underline{n}=16$ : Marriott 1986). wholly different

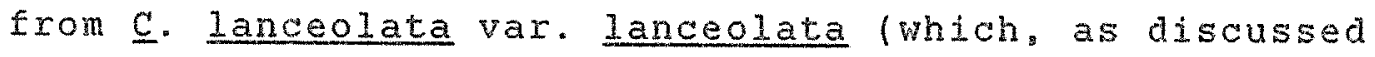
above, displayed tetraploid banding patterns in the populations sampled). In past treatments petal color. described as "golden yellow" by Davis (1952, 1966) and "deep yellowish-orange" by Hitchcock et al. (1964), was the primary character used to distinguish ‥ lanceolata var. Elava from related taxa at the level of species las $\underline{C}$. Elava: Davis 1952) or variety (Davis 1966. Hitcheock et al. 1964). However, PCAs of our morphological data indicated that the characters most important for distinguishing $\underline{C}$. lanceolata var. Elava Exom typical C. Ianceolata are related to leaf morphology (length/width ratio and venation) and petal shape (length/width ratio and apex outline).

Davis (1952) described the leaves of c. lanceolata var. flava as "Iinear or lance-Iinear," as compared to "stem 


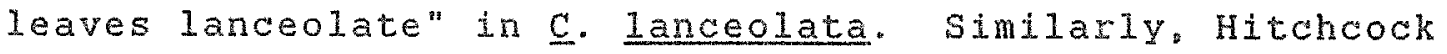
et al. (1964) described the stem leaves of $\underline{\text { C. Ianceolata }}$ var. Elava as "Ianceolate or narrowly oblong. several times longer than broad" and those of $\underline{C}$. lanceolata (represented by var. chrysantha) as "broadly eliptic to ovate. (1)1.5$2.5(4) \mathrm{cm}$ long. usually over $1 / 3$ as broad." Our study showed that the leaves of $C$. lanceolata var. flava average approximately seven times longer than wide, while those of

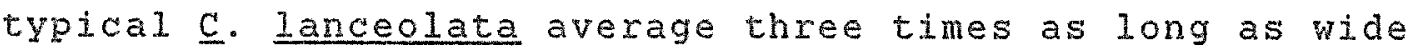
(Table 2). These numeric differences are in accordance with the earlier, largely qualitative leaf shape differences described for these taxa.

Historically, it is interesting to note that Rydberg (1922) recognized the patterns in leaf venation that distinguish

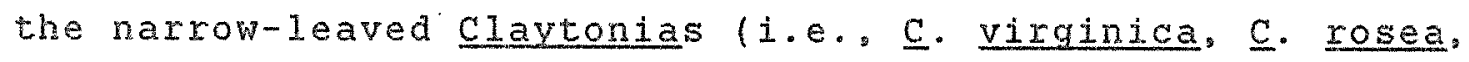

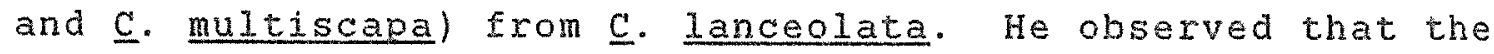
former group has leaves "1-ribbed or indistinctly 3-ribbed," While the latter taxon has leaves that are "distinctiy triple-ribbed." Our results uphold this as a valid and important means of distinguishing the narrow-leaved Claytonia populations from those of typical C. Ianceolata in the northern Rocky Mountains; the leaves of $\underline{C}$. lanceolata var. Elava have only one distinct vein (the midvein), while populations of typical $\underline{c}$. lanceolata have leaves with two prominent lateral veins in addition to the midvein (Table 4). 
Davis (1952) also distinguished $\underline{C}$. Lanceolata var. Elava from typical c. lanceolata by petal apex outline, describing the former as having petals "rounded at the apex," and the latter with petals "retuse or emarginate." Our studies

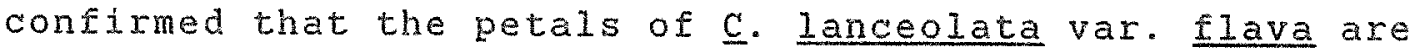
rounded at the apex, while those of typical C. Ianceolata are usually retuse or emarginate (Table 4). In addition, the results of both the field and morphological studies confirmed that the petals of $\underline{C}$. Ianceolata var. Elava are more nearly oval in shape, while those of $\underline{C}$. lanceolata are most often obovate, and frequently narrowly so. These results also concur with the descriptions by Davis (1952).

In addition to the morphological analyses, isozyme electrophoresis also clearly indicated that $\underline{C}$. lanceolata var. flava is specifically distinct from typical c. lanceolata. The mean genetic identity between the latter species and populations representing $\underline{C}$. Ianceolata var. Elava $(0.69--$ WILL NEED TO REVISE) is close to the mean between congeneric species $(0.67)$ presented in several reviews (Crawford 1983: Gottlieb 1981).

secondly, the results of our studies revealed that the diploid represented by populations assignable to $\underline{C}$. lanceolata var. Elava includes conspecific yellow- and white-flowered plants. In this and other cases, flower 
color has been found to be of limited use in delineating natural taxonomic relationships within the genus. Elsewhere in North Anerica, several other predominantly white- or pink-flowered taxa in Claytonia include named or unnamed yellow-flowered forms. Examples include C. Ianceolata var. chrysantha (Douglas and Taylor 1972). C. virginica L. var. hammondiae (Kalmbacher) Doyle, Lewis and Snyder (Snyder 1992), and a recently discovered population of $\underline{C}$. Caroliniana Michaux in Maryland that contains yellowflowered plants in addition to typical white- to pinkflowered plants (Snyder 1992). Such color forms are probably best viewed as minor variants within their respective taxa. They probably do not typically warrant taxonomic recognition, except in cases where their populations are correlated with ecological, genetic, geographic, and/or further morphological segregation (as is the case for $\underline{C}$. virginica var. hammondiae) (snyder 1992). In the case of $\underline{c}$. Ianceolata var. chrysantha, Douglas and raylor (1972) found that, based on morphological, ecological, and biochemical analyses, "..there is no significant difference between the yellow and white forms of Claytonia lanceolata, other than petal color," and that "( $t$ he difference in petal color is most likely due to one or very few genes, as evidenced by the virtual lack of intermediate color forms." They concluded that "..there is no basis for the recognition of var. chrysantha..." (Douglas and Taylor 1972). The results of our studies indicate the 
same situation with respect to the yellow and white flover color phenotypes of " $\underline{C}$. lanceolata var. Elava." Plants of the two color phenotypes are biotically sympatric in at least four populations in the northern Rocky Mountains, and these phenotypes reflect little or no morphological or isozyme differentiation within or among those populations. While there was some genetic differentiation among populations of $\underline{C}$. lanceolata var. Elava, plants of the two flover color phenotypes are "contaxonomic"; at the four sites where they are biotically sympatric, individuals of the two phenotypes are nearly or completely identical genetically. This suggests that in such cases they are part of the same breeding population, that flower color represents simple genetic differences (i.e., determined by one or a few genes), and that flower color does not warrant taxonomic recognition in this diploid.

Lastly, the herbarium morphological study revealed a strong similarity between $\underline{C}$. rosea and $\underline{C}$. lanceolata vars. Elava and multiscapa (Fig. 3). The latter variety, all collections of which are white-flowered, is reported by Hitchcock et al. (1964) as occurring in "Yellowstone National Park and vicinity." The morphological similarity of var. multiscapa to var. Ilava, and its complete geographic overlap with stations of white- and/or yellowflowered populations of the latter entity, support the notion that var. multiscapa represents the same taxon as the 
white-flowered form of var. "Elava." Claytonia rosea probably represents more southerly, white- to pink-flowered populations of the same narrow-leaved taxon as well. Iike the populations of $\mathrm{C}$. Ianceolata var. flava sampled in Montana and Wyoming, numerous Colorado populations of $\underline{C}$. rosea are diploid ( $\underline{n}=8$; Halleck and Wiens 1966).

In sumary, electrophoretic and morphological data clearly revealed that $\underline{C}$. Lanceolata var. flava does not belong in

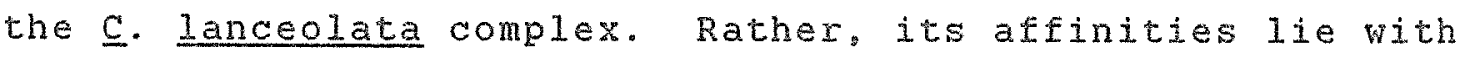
the narrow-leaved group of species that includes $\underline{C}$. rosea. c. tuberosa and $\underline{c}$ virginica. On the basis of the herbarium

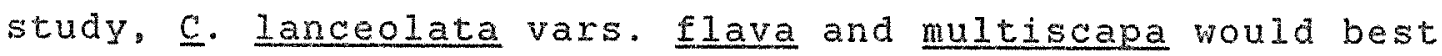
be treated as synonyms of $C$. rosea, until the relationship of the latter to $\mathrm{C}$. tuberosa (a white-flovered species of the Yukon, Alaska and Siberia: Miller 1992) is more fully evaluated. Further analysis may indicate that $\underline{C}$. rosea and C. Ianceolata vars. Elava and multiscapa should all be included in $\underline{C}$. tuberosa as members of a wide-ranging taxon, the latter name having nomenclatural priority (J. Miller, pers. comm.). Formal nomenclatural changes are not made here, but left for upcoming publication of a complete revision of the genus (Miller 1992).

Conservation status. In the northern Rocky Mountains. narrow-leaved populations of claytonia consisting wholly or partially of yellow-flowered individuals remain uncommon 
(ten such populations are now known from Idaho, Montana and Wyoming). However, the conspecific narrow-leaved, whiteflowered populations are more common and widespread. These White-flowered populations occur over a larger area in northwestern and north-central wyoming, and south-central to southwestern Montana. Populations of both flower color phenotypes are usually very large in size and areal extent, and at least 30 populations consisting of one or both forms have now been documented in Montana Montana Natural Heritage Program, Helena). Because the yellow and white flower color phenotypes are conspecific, $\underline{C}$. lanceolata var. flava is not in need of protective listing, regardless of its eventual taxonomic disposition: it should be removed from further consideration for federal listing as a threatened or endangered plant. This conclusion is further substantiated by the observation that this taxon appears to be conspecific with $\underline{\text { C. rosea. }}$

When necessary, protection of endangered plant taxa should be preceded by evaluation of their taxonomic status. In the case of C. Ianceolata var. Elava, modern systematic techniques have proven invaluable for this purpose. These techniques will be increasingly useful in ensuring that the Iimited funds available for endangered species conservation are devoted to taxonomically deserving taxa and the maintenance of genetic diversity. 


\section{ACKNOWLEDGMENTS}

Funding for these studies was provided to the Montana Natural Heritage Progran by the U.S. Forest service and the U.S. Fish and Wildife service. Kenton Chambers, Jeff Doyle, Hollis Marriott, John Miller and David Snyder provided helpful information and comments on the manuscript. Duane Atwood, Angela Evenden, Robert Moseley, Jan Nixon, Lisa Roe. Frank Schitoskey and Ken Scow assisted with the field work. Tracy Tucker assisted with the electrophoretic analysis. We gratefully acknowledge the curators and their assistants from the herbaria cited for making loans available.

\section{IITERATURE CITED}

Cravford, D. J. 1983. Phylogenetic and systematic inferences from electrophoretic studies. Pp. 257-287 in Isozymes in Plant Geneties and Breeding, Part A, eds. S. D. Tanksley and T. J. Orton. Amsterdam, Netherlands: Elsevier Science Publishers.

Davis, R. J. 1952. Flora of Idaho. Dubuque: Wm. C. Brown Company.

Davis, R. J. 1966. The North American perennial species of Claytonia. Brittonia 18:285-303. 
Dorn, R. D. 1984. Vascular Plants of Montana. Cheyenne: Mountain west Fublishing.

Douglas, G. W. and R. J. Taylor. 1972. The biosystematics, chemotaxonomy, and ecology of claytonia lanceolata in western Washington. Canadian Journal of Botany 50:2177-2187.

Gottlieb. L. D. 1981. Electrophoretic evidence and plant populations. Progress in Phytochemistry $7: 1-45$.

Halleck, D. K. and D. Wiens. 1966. Taxonomic status of Claytonia rosea and $\underline{C}$. lanceolata (Portulacaceae). Annals of the Missouri Botanical Garden 53:205-212.

Hitchcock, C. L. and A. Cronquist. 1964. Vasculax Plants of the Pacific Northwest, Part 2. Seattle: University of Washington Press.

Marriott, H. 1986. Status report, Claytonia lanceolata var. Elava. Unpublished report to U. S. Fish and Wildilfe Service, Denver, Colorado. Rocky Mountain Heritage Task Force, Laramie, Wyoming.

Miller, J.M. 1992. Claytonia. Elora of North America. In preparation. 
Nelson, A. 1900. New plants from Wyoming - XII. Bulletin of the Torrey Botanical Club 27:258-274.

Nelson, A. 1926. Taxonomic studies. 2, Miscellaneous new species. University of flyoming publications in Botany $1: 122-143$

Ordzykoski, I. J., and I. D. Gottlieb. 1984. Duplication of genes coding 6-phosphogluconate dehydrogenase (6-PGD) in Clarkia (Onagraceae) and their phylogenetic implications. Systematic Botany $9: 479-489$.

Rydberg, P. A. 1922. Flora of the Rocky Mountains. Hafner, 2nd edition.

Shelly. J. S. 1989. Status review of Claytonia lanceolata var. flava, Beaverhead, Deerlodge and Gallatin National Forests, Montana. Unpublished report to U. S. Forest Service, Region 1. Missoula, Montana. Montana Natural Heritage Program, Helena.

Snyder, D. B. 1992. A new status for New Jersey's yellow spring beauty. Bartonia $57: 39-49$.

Soltis, D. E., C. H. Haufler, D. C. Darrow, and G. J. Gaustony. 1983. Starch gel electrophoresis of ferns: A 
compliation of grinding buffers. gel and electrode buffers, and staining schedules. American Fern Journal 73:9-27.

Swofford, D. L. and R. B. Selander. 1981. BIOSYS-1: A Fortran program for the comprehensive analysis of electrophoretic data in population genetics and systematics. Journal of Heredity $72: 281-283$.

U. S. Fish and Wildife Service. 1985. Notice of review. Federal Register 50:39525-39584.

Wendel, J. F. and N. E. Weeden. 1989. Visualization and interpretation of plant isozymes. Pp. 5-45 in Isozymes in plant biology, eds. D. E. Soltis and P. S. Soltis. Portland: Dioscorides Press.

Wilkinson, I. 1986. SYSTAT: The system for statistics. Evanston, Illinois.

Wolf. P.G. 1988. Analysis of electrophoretic variation in Claytonia lanceolata vars. Ianceolata and Elava. Unpublished report to Montana Natural Heritage Program. Helena, Montana. Washington State University, Pullman. 
TABLE 1. Populations of claytonia lanceolata vars. flava and lanceolata analyzed in isozyme and field morphological studies. Flower color phenotypes of var. Elava were sampled as separate "populations" where they are biotically sympatric (Anaconda, Champion, Vipond, and Wyoming). Vouchers are deposited at MONTU; numbers marked with * have duplicates deposited at OSC. $+=$ the Burton park population of white-flowered flava was not included in the electrophoretic study.

Taxon Abbreviation Collection data

C. 1. var. Elava

\begin{tabular}{|c|c|}
\hline ANACON WHITE & $\begin{array}{l}\text { Montana, Deer Lodge Co. } \\
\text { She } 11 \mathrm{y} \text { \& Lesica } 1412^{*}\end{array}$ \\
\hline YELLOW & $\begin{array}{l}\text { Montana, Deer Lodge Co. } \\
\text { Sheliy \& Lesica } 1413^{*}\end{array}$ \\
\hline BOULDER WHITE & $\begin{array}{l}\text { Montana, Sweet Grass Co } \\
\text { Shelly } 1617\end{array}$ \\
\hline BURTON PARK WHITE+ & $\begin{array}{l}\text { Montana, Silver Bow Co. } \\
\text { Shelly, schassberger } \\
\text { \& Schitoskey } 1504\end{array}$ \\
\hline CHAMPION YELLOW & $\begin{array}{l}\text { Montana, Jefferson Co. } \\
\text { Shelly } 1417^{*}\end{array}$ \\
\hline CHAMPION WHITE & $\begin{array}{l}\text { Montana, Jefferson Co. } \\
\text { Shelly \& Lesica } 1423^{*}\end{array}$ \\
\hline HEBGEN YELLOW & $\begin{array}{l}\text { Montana, Gallatin Co. } \\
\text { Shelly \& Lesica } 1419^{\circ}\end{array}$ \\
\hline VIPOND YELLOW & $\begin{array}{l}\text { Montana, Beaverhead Co. } \\
\text { Shelly \& Scow } 1444^{*}\end{array}$ \\
\hline VIPOND & $\begin{array}{l}\text { Montana. Beaverhead Co. } \\
\text { She11y \& Scow } 1445^{*}\end{array}$ \\
\hline WYOMING YELLOW & $\begin{array}{l}\text { Wyoming, Eremont Co. } \\
\text { Shelly \& Lesica } 14.6^{*}\end{array}$ \\
\hline WYOMING WHITE & $\begin{array}{l}\text { Wyoming, Fremont Co. } \\
\text { sheliy \& Lesica } 1447^{*}\end{array}$ \\
\hline
\end{tabular}

C. I. var. lanceolata

\begin{tabular}{|c|c|}
\hline ANACON LANCEOL & $\begin{array}{l}\text { Montana, Deer Lodge Co. } \\
\text { Shelly \& Lesica } 1411\end{array}$ \\
\hline CHAMPION LANCEO & $\begin{array}{l}\text { Montana, Jefferson Co. } \\
\text { Shelly \& Lesica } 1422\end{array}$ \\
\hline HEBGEN LANCEOL & $\begin{array}{l}\text { Montana, Madison Co. } \\
\text { Shelly \& Lesica } 1420^{\circ}\end{array}$ \\
\hline VIPOND LANCEOL & $\begin{array}{l}\text { Montana, Beaverhead Co. } \\
\text { Sheily } 1201\end{array}$ \\
\hline WYOMING LANCEOL & $\begin{array}{l}\text { Wyoning, Teton Co. } \\
\text { Shelly \& Lesica } 1448 *\end{array}$ \\
\hline
\end{tabular}


TABLE 2. Taxon means, ranges and standard deviations for Eield morphological data. Claytonia lanceolata vars. Elava and lanceolata.

Yel10w Elava white flava lanceolata

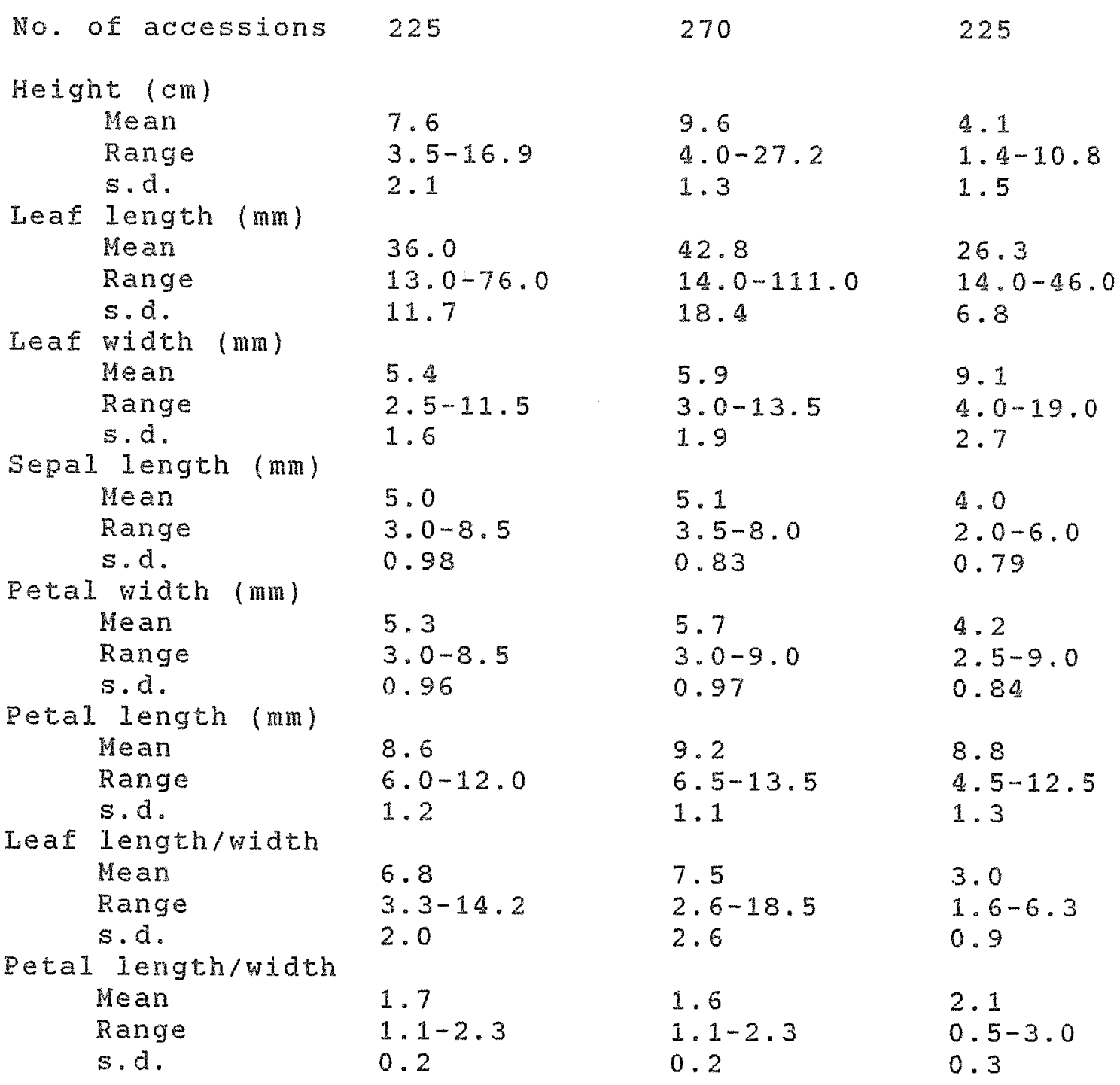


TABLE 3. Loadings of the first two principal components for the quantitative characters measured in the field morphology studies.

\begin{tabular}{lrr} 
& \multicolumn{2}{c}{ Component } \\
Characteristics & \multicolumn{1}{c}{1} \\
\hline Petal width & 0.832 & 0.114 \\
Leaf length & 0.807 & 0.177 \\
Height & 0.789 & 0.033 \\
Leaf length/width & 0.755 & -0.426 \\
Sepal length & 0.700 & 0.202 \\
Petal length/width & -0.646 & 0.395 \\
Leaf width & -0.189 & 0.847 \\
Petal length & 0.474 & 0.702
\end{tabular}


TABLE 4. Taxon means, ranges and standard deviations for quantitative and qualitative morphological characters from herbarium specimens, Claytonia lanceolata vars. Elava. lanceolata, and multiscapa, and c. rosea. For some characters, the number of accessions was less than that shown in the first line: exceptions are given in parentheses after the means.

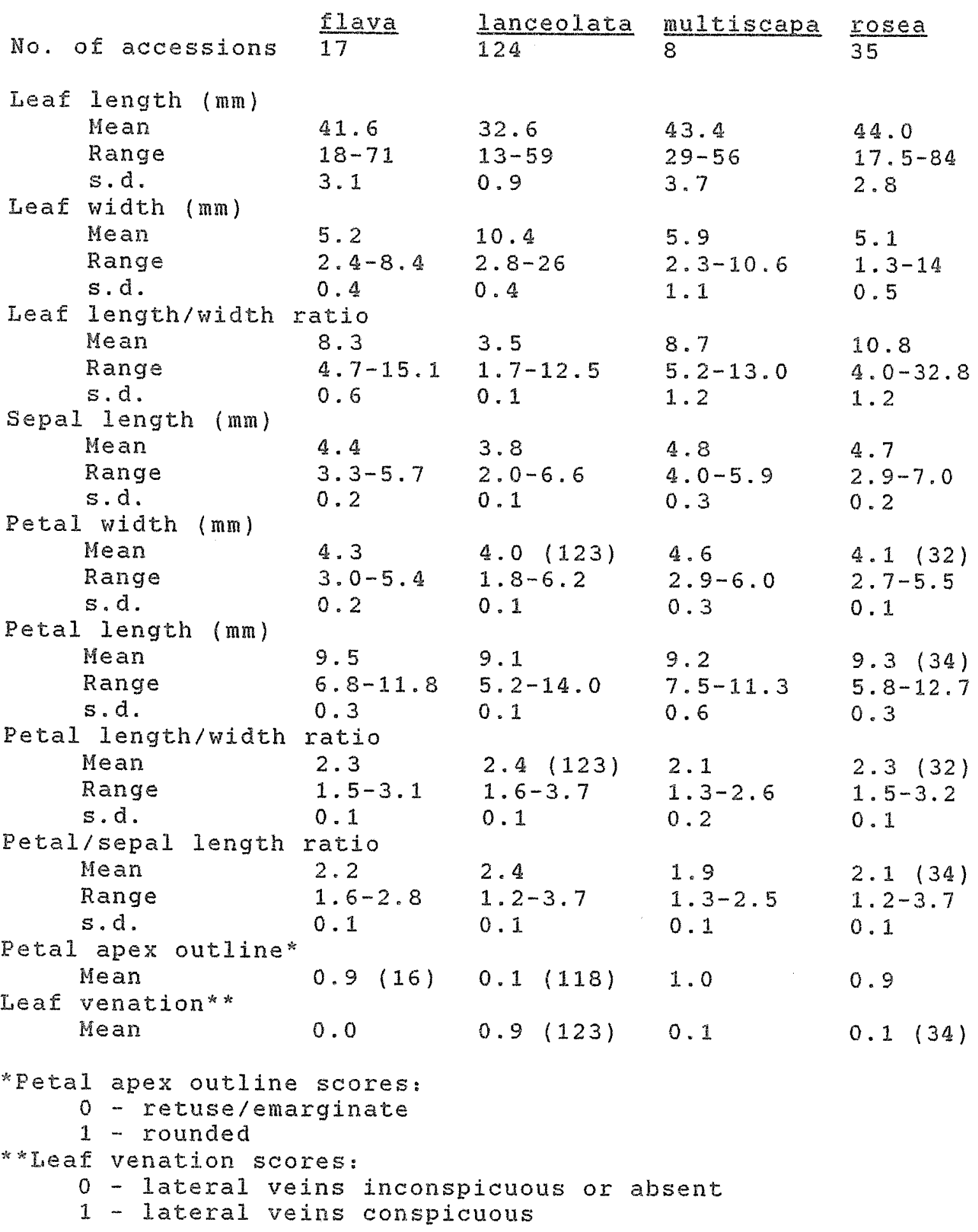


TEBLE 5. Loadings of the first two principal components for the quantitative and qualitative characters used in the herbartum morphology study.

\begin{tabular}{lrr} 
& \multicolumn{2}{c}{ Component } \\
\cline { 2 - 3 } Characteristics & \multicolumn{1}{c}{1} & \multicolumn{1}{c}{2} \\
\hline Venation & -0.840 & 0.039 \\
Petal apex outline & 0.830 & -0.051 \\
Leaf length/width & 0.775 & -0.061 \\
Leaf width & -0.630 & 0.472 \\
Petal/sepal ratio & -0.607 & 0.121 \\
Sepal length & 0.588 & 0.450 \\
Petal width & 0.069 & 0.872 \\
Petal length & -0.095 & 0.778 \\
Leaf length & 0.344 & 0.500 \\
Petal length/width & -0.174 & -0.409
\end{tabular}

